Bull. Chem. Soc. Ethiop. 2021, 35(3), 537-550.

(c) 2021 Chemical Society of Ethiopia and The Authors

ISSN 1011-3924

DOI: https://dx.doi.org/10.4314/bcse.v35i3.6

Printed in Ethiopia

Online ISSN 1726-801X

\title{
PEROXIDASE-LIKE ACTIVITY OF HEMOGLOBIN-BASED HYBRID MATERIALS AGAINST DIFFERENT SUBSTRATES AND THEIR ENHANCED APPLICATION FOR $\mathrm{H}_{2} \mathrm{O}_{2}$ DETECTION
}

\author{
Cevahir Altinkaynak ${ }^{1 *}$, Merve Turk², Murat Ekremoğlu ${ }^{3}$ and Nalan Özdemir ${ }^{2}$ \\ ${ }^{1}$ Department of Plant and Animal Production, Avanos Vocational School, Nevsehir Haci Bektas \\ Veli University, 50500, Nevsehir, Turkey \\ ${ }^{2}$ Department of Chemistry, Faculty of Science, Erciyes University, 38039, Kayseri, Turkey \\ ${ }^{3}$ Department of Medical Biochemistry, Faculty of Medicine, Istinye University, 34010, Istanbul, \\ Turkey
}

(Received November 13, 2020; Revised January 20, 2022; Accepted January 22, 2022)

\begin{abstract}
Organic-inorganic hybrid nanoflowers method with unique properties are preferred than conventional immobilization methods for the past decade. Hereemoglobin-based hybrid material $(\mathrm{HbNFs} @ \mathrm{Cu})$ was synthesized under different experimental conditions ( $\mathrm{pH}$ 5.0-9.0 and 0.01-0.50 $\mathrm{mgmL}^{-1}$ of hemoglobin) obtaining a material size of 9-10 $\mu \mathrm{m}$. The encapsulation percentage and weight yield of HbNFs@Cu were determined as 100\% and $6.7 \%$, respectively. The peroxidase-like activities of the material against different substrates (ABTS and Guaiacol)were compared to free hemoglobin. The HbNFs@Cu hybrid structure exhibited $V_{\max }$ of 3.6995 EU/mg and a Michaelis-Menten constant $\left(K_{M}\right)$ of $0.1357 \mathrm{mM} / \mathrm{mL}$. The HbNFs@Cu hybrid material was then used to catalyze the oxidation of a peroxidase substrate ABTS to the pigmented product, which provided a colorimetric and spectrophotometric detection of $\mathrm{H}_{2} \mathrm{O}_{2}$. The linear operating range, detectable colorimetrically as $\mathrm{H}_{2} \mathrm{O}_{2}$ sensor, is $0.005-0.0042 \mathrm{mM}$, while the linear operating range, detectable spectrometically, is $0.003-0.0042 \mathrm{mM}$. The limits of detection of colorimetric and spectrophotometric sensors were $0.005 \mathrm{mM}$ and $0.003 \mathrm{mM}$, respectively. Collectively, these results showed that HbNFs@Cu can be used as colorimetric biosensor for $\mathrm{H}_{2} \mathrm{O}_{2}$ in potential applications such as pharmaceutical food, biomedical, environmental, and industrial.
\end{abstract}

KEY WORDS: Hydrogen peroxide, Hemoglobin, Hybrid Material, Colorimetric assay

\section{INTRODUCTION}

Organic-inorganic hybrid nanoflower has recently attracted attention as an effective nanostructure with excellent properties and a novel method of protein (enzyme) immobilization [1-6]. Nanoflowers do not share the disadvantages of conventional immobilization techniques such as mass transfer limitations, low stability, low enzymatic activity, and long production processes [6, 7] and are high-efficiency catalysts due to large surface-to-volume ratio [8]. The nanoflower, which has nano-sized plates, has been applied to drug transportation, gene therapy, biosensor diagnosis and therapy [9]. Protein-based biomaterials are a particularly effective tool for characterizing the target analyte [10-12]. To date, various researches have been carried out using such materials as carbon, metal, metal oxide-based nanoparticles, and metal complexes to design functional synthetic materials with peroxidase and catalase-like activities [13-15]. Heme groupcontaining proteins such as hemoglobin $(\mathrm{Hb})$, myoglobin and cytochrome $\mathrm{C}$ exhibit peroxidaselike activity due to their electroactive heme groups and can be used to reduce hydrogen peroxide and as $\mathrm{H}_{2} \mathrm{O}_{2}$ sensors $[16,17]$. Among these, hemoglobin is widely used in the analysis because of its well-known molecular structure, its cheapness, commercial usable and high stability [10, 18]. Hemoglobin is a $5.5 \mathrm{~nm}$ sized protein with tetrameric, globuler and oxygen carrier, each monomer weighing $17 \mathrm{kDa}[11,16,19,20]$.

*Corresponding author. E-mail: caltinkaynak@nevsehir.edu.tr

This work is licensed under the Creative Commons Attribution 4.0 International License 
The peroxidase-like catalytic activity of hemoglobin is slower and lower than the natural peroxidase enzyme [19]. The natural hemoglobin molecule was therefore immobilized to different types of nanocomposites for the production of $\mathrm{H}_{2} \mathrm{O}_{2}$ sensors such as $\mathrm{Hb}$ /Pluronic $\mathrm{P} 123$-nanografen platelet [21], $\mathrm{Hb} /$ Collagen micro belt [22], and $\mathrm{Hb} / \mathrm{Ag}$ sol films [23] and hemoglobin-DNA conjugate on nanoporous gold thin film[18]. However, the difficult working principles of these methods, their weak determination limits and their operation within a narrow linear range limit their industrial use. For this reason, there is a need for the development of effective, reliable and highly sensitive nanostructures, easy application to $\mathrm{H}_{2} \mathrm{O}_{2}$ determination, and rapid response. It is known that the stabilities and activities of organic structures immobilized by organic-inorganic hybrid nanoflowers method are higher than free molecules.

In this area of research, by Gao et al. obtained two different biomolecules [24, 25]. The hemoglobin- $\mathrm{Mn}_{3}\left(\mathrm{PO}_{4}\right)_{2}$ hybrid nanoflowers were synthesized and found their opulent electroactive [25]. At the same time, Gao et al. reported that the synthesized $\mathrm{Hb}-\mathrm{Cu}_{3}\left(\mathrm{PO}_{4}\right)_{2} \mathrm{HNFs}$ obtained an excellent stability and exhibited greater catalytic activity than free $\mathrm{Hb}$ against Rhodamine 6G substrate [24]. As we know, an enzyme substrate is the material upon which an enzyme acts, and enzymes exhibit different reactions against different substrates [26]. Inquiry about the peroxidase-like activity of hemoglobin-inorganic hybrid nanoflowers against different substrates is needed.

The current work aims for a deeper understanding of the reaction of hemoglobin-based hybrid materials against different substrates. So, it will be provided to forma hemoglobin-based hybrid material (HbNFs@Cu) with a very low level of peroxidase mimic activity, commercially usable, extremely cheap hemoglobin molecule (as a organic part) and inorganic part $\mathrm{Cu}$ (II) ion and phosphate buffer. It is known that hemoglobin molecule shows structural changes at various $\mathrm{pH}$ values in vitro conditions [27]. For this reason, hybrid materials were synthesized under different experimental conditions, and the morphologies of hybrid materials were characterized using SEM, EDX, XRD and FTIR. The enzymatic activity profiles of HbNFs@Cu against different substrates were examined, and a minimum linear working range was detected for the determination of $\mathrm{H}_{2} \mathrm{O}_{2}$ under optimum conditions.

\section{EXPERIMENTAL}

\section{Chemicals and materials}

Hemoglobin from bovine blood (H2625), bovine serum albumin (A7906), guaiacol and phosphoric acid were purchased from Sigma-Aldrich. Copper(II) sulfate pentahydrate was purchased from ISOLAB. ABTS was purchased from Roche. Coomassie plus protein assay reagent was purchased from Thermo Scientific. $\mathrm{KCl}, \mathrm{NaCl}, \mathrm{Na}_{2} \mathrm{HPO}_{4}, \mathrm{KH}_{2} \mathrm{PO}_{4}, \mathrm{NaH}_{2} \mathrm{PO}_{4}, \mathrm{NaOH}$, $\mathrm{H}_{2} \mathrm{O}_{2}$, ethyl alcohol and $\mathrm{HCl}$ were purchased from Merck. All chemical reagents were of analytical grade. Aqueous solutions were prepared using deionised water.

\section{Fabrication of HbNFs@Cu}

For the synthesis of $\mathrm{HbNFs} @ \mathrm{Cu}$; hemoglobin and $\mathrm{CuSO}_{4} .5 \mathrm{H}_{2} \mathrm{O}$ solution were used as the organic and inorganic component, respectively. $0.8 \mathrm{mM} \mathrm{CuSO}_{4} .5 \mathrm{H}_{2} \mathrm{O}$ solution adjusted phosphate buffer saline buffer $(10 \mathrm{mM}, \mathrm{pH} 5.0-9.0)$ containing various concentrations of hemoglobin (0.01-0.50 $\mathrm{mg} \mathrm{mL} L^{-1}$ of total solution) for each tube. After the solution was incubated for 3 days at $4{ }^{\circ} \mathrm{C}$, centrifuge separation produced a pellet. The pellet was washed three times with water to remove unbounded protein molecules. To determine the encapsulated protein in the nanoflower, the protein amount was applied to the supernatant after incubation via the Bradford protein assay. 
Characterization of HbNFs@Cu

Scanning electron microscopy (SEM) provides information on the surface morphology and particle size of the material. The morphologies of the synthesized HbNFs@Cu were visualized with SEM (LEO 440 Computer Controlled Digital). The presence of Cu, P, N, O, C and $\mathrm{Cl}$ metals in HbNFs@Cu were detected by Energy dispersed X-ray analysis (EDX). The chemical structures of the HbNFs@Cu hybrid structures were confirmed by FTIR analysis (Perkin Elmer 400 FT-IR Spectrometer Spotlight 400 Imaging System) at a range of $4000-450 \mathrm{~cm}^{-1}$ wavenumbers. The crystal structures of HbNFs@Cu were illuminated from $10^{\circ}$ to $80^{\circ}$ by XRD (X-ray diffraction) analysis.

Measurement of peroxidase-like activities of HbNFs@Cu

The peroxidase-like activities of the HbNFs@Cu were examined in two different methods compared to free hemoglobin. The first method [6] began by weighing 3 mg of HbNFs@ $\mathrm{Cu}$ synthesized in optimum $\mathrm{pH}$ condition. Each was taken into a $15 \mathrm{~mL}$ tube. $1 \mathrm{~mL}$ of PBS buffer in different $\mathrm{pHs}, 1 \mathrm{~mL}$ of $22.5 \mathrm{mM} \mathrm{H}_{2} \mathrm{O}_{2}$ solution and finally $1 \mathrm{~mL}$ of $45 \mathrm{mM}$ guaiacol solution were added to the each tubes. The reaction mixtures were stirred and incubated at room temperature for $25 \mathrm{~min}$. After centrifugation, the spectrophotometric absorbances at $470 \mathrm{~nm}$ were measured using UV-spectrometer (HITACHI). The catalytic activity of free hemoglobin in equal amount was performed with the same method.

The second method [28] began by weighing 3 mg of HbNFs@Cu in optimum pH condition. Each was taken into a $15 \mathrm{~mL}$ tube. $1 \mathrm{~mL}$ of PBS buffer in different pHs, $1 \mathrm{~mL}$ of $25 \mathrm{mM} \mathrm{H}_{2} \mathrm{O}_{2}$ solution and finally $1 \mathrm{~mL}$ of $1 \mathrm{mM}$ ABTS solution were added to each tube. The reaction mixtures were stirred and incubated at room temperature for $25 \mathrm{~min}$. After centrifugation, the spectrophotometric absorbances at $420 \mathrm{~nm}$ were measured using UV-spectrometer (HITACHI). The catalytic activity of free hemoglobin in equal amount was performed with the same method.

\section{Michaelis-Menten kinetic parameters of HbNFs@Cu}

Kinetic parameters of HbNFs@Cu were determined by ABTS concentrations varying from 0.08$2.7 \mathrm{mM} \mathrm{mL}^{-1}$ and evaluated for peroxidase-like activities in phosphate buffer solution ( $\mathrm{pH} 5$ ). Michaelis-Menten constant $\left(\mathrm{K}_{\mathrm{M}}\right.$ and $\mathrm{V}_{\max }$ of HbNFs@Cu) was calculated from Lineaweaver-Burk plot $(1 / \mathrm{V}$ and $1 / \mathrm{S})$.

\section{Reusability of HbNFs@Cu}

The reusability of HbNFs@Cu was carried out under optimum activity conditions for 10 cycles of reuse. After each cycle, the HbNFs@Cu was centrifuged for 5 min at 5000 g, washed with PBS buffer and readied for the next cycle.

\section{Colorimetric and spectrophotometric measurements of $\mathrm{H}_{2} \mathrm{O}_{2}$ using $\mathrm{HbNFs@Cu}$}

The various concentrations of $\mathrm{H}_{2} \mathrm{O}_{2}$ solutions were prepared in water and the technical feasibility of $\mathrm{H}_{2} \mathrm{O}_{2}$ colorimetric sensing was carried out in activity reaction system. Typically $3 \mathrm{mg}$ of HbNFs@Cu, $1 \mathrm{~mL}$ of PBS buffer (10 mM, pH 5), $1 \mathrm{~mL}$ of $4 \mathrm{mM}$ ABTS solution and $1 \mathrm{~mL}$ of various concentrations of $\mathrm{H}_{2} \mathrm{O}_{2}$ solution $(0.008-2 \mathrm{mM})$ were added to the tubes. The reaction mixture was stirred and incubated at room temperature for $25 \mathrm{~min}$ with stirring. After centrifugation, the spectrophotometric absorbance at $420 \mathrm{~nm}$ and colorimetric response was determined both using UV-spectrometer (HITACHI) and visually. 


\section{RESULTS AND DISCUSSION}

\section{Influence of synthesis conditions on the formation of HbNFs@Cu}

Hemoglobin was used as an organic component and $\mathrm{Cu}$ (II) ions as an inorganic component in the synthesis of the hybrid material. The experimental section describes the synthesis of HbNFs@Cu. The effects of the synthesis medium $\mathrm{pH}$ (5-9) and hemoglobin amount $\left(0.01-0.5 \mathrm{mg} \mathrm{mL}^{-1}\right)$ on the formation of HbNFs@Cu were examined. The scanned experimental parameters of $\mathrm{HbNFs} @ \mathrm{Cu}$ show that the product could not be obtained when the synthesis medium $\mathrm{pH}$ was 5 . We know the isoelectric point $(\mathrm{pI})$ of hemoglobin is 6.7 [24]; below this $\mathrm{pH}$, no nanoflower precipitates form [29]. The blue-brown colored pellet was observed in the other $\mathrm{pH}$ conditions.

To determine the encapsulation and weight percentage of $\mathrm{HbNFs} @ \mathrm{Cu}$, the protein assay was applied on the supernatant after incubation. The encapsulation rate was found to be $0 \%$ due to no product at $\mathrm{pH} 5$. Weight percentage also could not be calculated. The HbNFs@Cu encapsulation percentage using $0.05 \mathrm{mg} \mathrm{mL}^{-1}$ hemoglobin in the reaction solution at $\mathrm{pH} 7$ was higher than under other conditions; the amount of product was $15 \mathrm{mg}$ and weight efficiency was $6.7 \%$. In previous studies Batule and co-workers [30] reported that the encapsulation efficiency of hybrid nanostructures containing $0.1 \mathrm{mg} \mathrm{mL}^{-1}$ laccase was calculated as $77 \%$. Zare et al. [31] indicated that the encapsulation efficiency of laccase- $\mathrm{Cu}^{2+}$ hybrid nanostructures containing $0.1 \mathrm{mg} \mathrm{mL}^{-1}$ of laccase enzyme was $64 \%$ and weight efficiency was $9 \%$. Recently, Gao et al. [24] have reported the encapsulation efficiency to drop from 87.75 to $58.47 \%$ with increasing of $\mathrm{Hb}$ concentration from 0.05 to $0.5 \mathrm{mgmL}^{-1}$ in the formation of hemoglobin- $\mathrm{Cu}_{3}\left(\mathrm{PO}_{4}\right)_{2}$ organic/inorganic hybrid nanoflowers. In another study, Gao [25] reported the hemoglobin weight ratio on the Hemoglobin$\mathrm{Mn}_{3}\left(\mathrm{PO}_{4}\right)_{2}$ hybrid nanoflower to increase from 0 to $24.86 \%$, while its encapsulation efficiency on hybrid nanoflower decreased from 64.36 to $4.39 \%$.

Figure 1 presents the SEM images showing the morphologies of HbNFs@Cu formed with $0.01 \mathrm{mg} \mathrm{mL}^{-1}$ (Figure 1a), $0.02 \mathrm{mg} \mathrm{mL}^{-1}$ (Figure 1b), $0.05 \mathrm{mg} \mathrm{mL}^{-1}$ (Figure 1c), $0.1 \mathrm{mg} \mathrm{mL}^{-1}$ (Figure 1d), $0.2 \mathrm{mg} \mathrm{mL}^{-1}$ (Figure 1e), and $0.5 \mathrm{mg} \mathrm{mL}^{-1}$ (Figure 1f) hemoglobin. All HbNFs@Cu obtained had a flower-like morphology, and all nanoflowers were uniform. At low hemoglobin amount (Figure 1a and Figure 1b), the petal density decreased and appeared to be thin. The product amount of HbNFs@Cu containing $0.01 \mathrm{mg} \mathrm{mL}^{-1}$ and $0.02 \mathrm{mg} \mathrm{mL}^{-1}$ hemoglobin were 7.0 and 9.3, respectively. At the $0.05 \mathrm{mg} \mathrm{mL}^{-1}$ concentration, the product amount was found $15 \mathrm{mg}$.

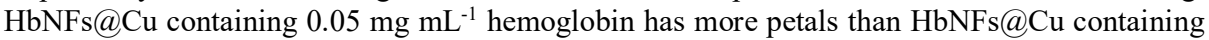
$0.01 \mathrm{mg} \mathrm{mL}^{-1}$ and $0.02 \mathrm{mg} \mathrm{mL}^{-1}$ hemoglobin. At the $0.05 \mathrm{mg} \mathrm{mL}^{-1}$ concentration, this structure is like to be a rose. The obtained product amount is more than HbNFs@Cu containing $0.01 \mathrm{mg}$ $\mathrm{mL}^{-1}$ and $0.02 \mathrm{mg} \mathrm{mL}^{-1}$ hemoglobin. But, at high hemoglobin amount (above $0.1 \mathrm{mg} \mathrm{mL}^{-1}$ ), the petal density increased and became more stringent than under other synthesis conditions. With the decreasing the $\mathrm{pH}$ value of PBS buffer; the surface of nanoflowers was rough and become more compact (Figure 2) and the average particle size of the HbNFs@ $\mathrm{Cu}$ increased. At pH 6 the product amounts of HbNFs@Cu containing $0.01 \mathrm{mg} \mathrm{mL}^{-1}, 0.02 \mathrm{mg} \mathrm{mL}^{-1}$ and $0.05 \mathrm{mg} \mathrm{mL}^{-1}$ hemoglobin were $3.2 \mathrm{mg}, 4.5 \mathrm{mg}$ and $4.9 \mathrm{mg}$. With the increasing the $\mathrm{pH}$ value of PBS, the surface of nanoflowers was scattered (Figure 3 and 4) and the amount of HbNFs@Cu varied between 3.2 $\mathrm{mg}$ and $5.9 \mathrm{mg}$.

Eventually, the optimum pH value and hemoglobin concentration for HbNFs@Cu were determined to be 7 and $0.05 \mathrm{mg} \mathrm{mL}^{-1}$, respectively (Figure 1c). The average particle size of the HbNFs@Cu was about 9-10 $\mu \mathrm{m}$. 
(a)

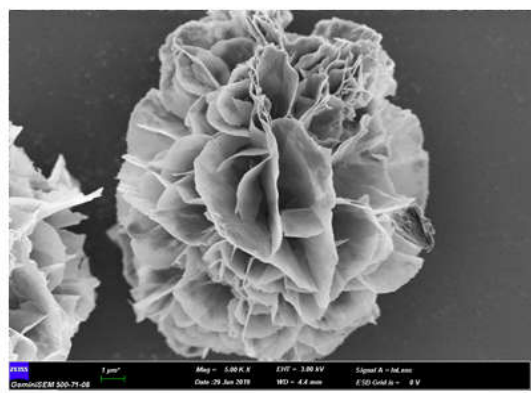

(c)

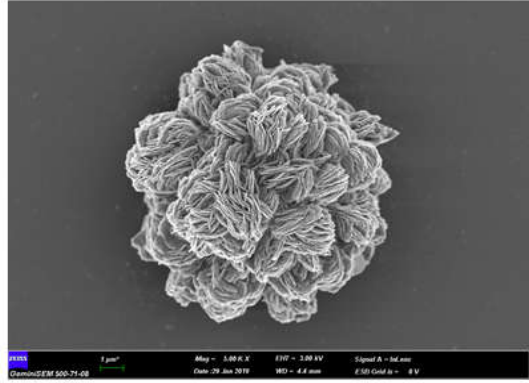

(e)

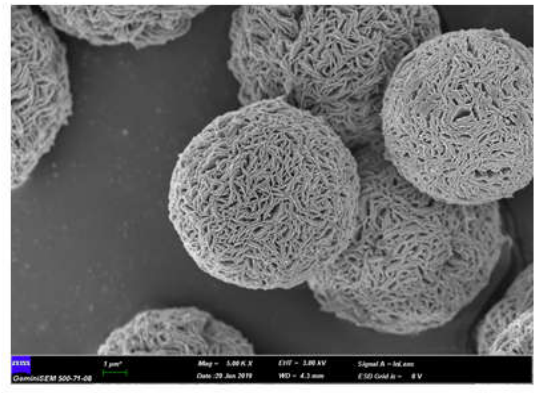

(b)

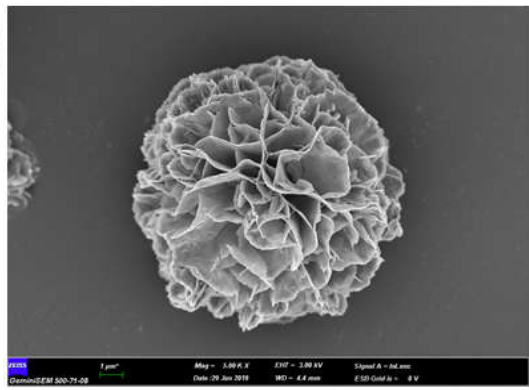

(d)

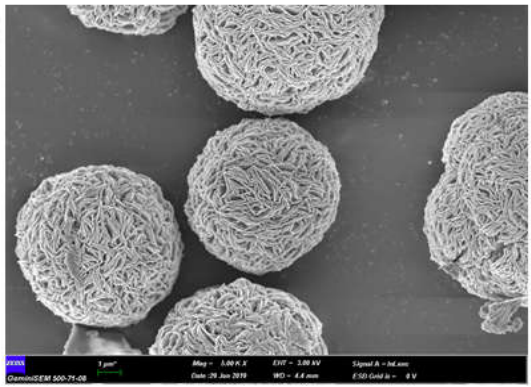

(f)

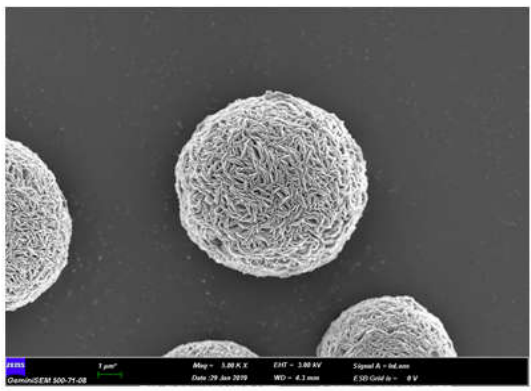

Figure 1. SEM images of HbNFs@Cu formed with varying hemoglobin concentrations: (a) 0.01 $\mathrm{mgmL}^{-1}$, (b) $0.02 \mathrm{mgmL}^{-1}$, (c) $0.05 \mathrm{mgmL}^{-1}$ (optimum condition), (d) $0.1 \mathrm{mgmL}^{-1}$, (e) $0.2 \mathrm{mgmL}^{-1}$, and (f) $0.5 \mathrm{mgmL}^{-1}\left[\mathrm{PBS}(10 \mathrm{mM}, \mathrm{pH} 7), \mathrm{Cu}^{2+}(0.8 \mathrm{mM}),+4{ }^{\circ} \mathrm{C}\right.$ and 3 days incubation].

(a)

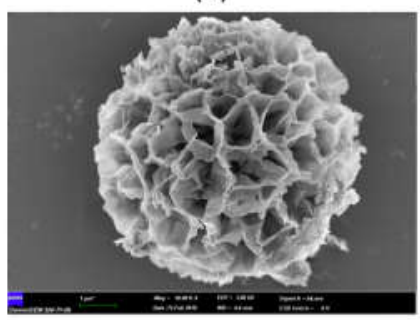

(b)

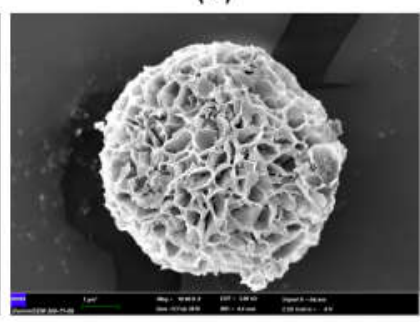

(c)

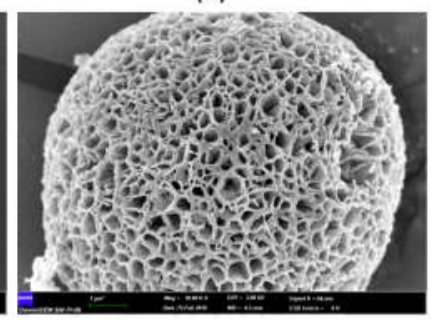

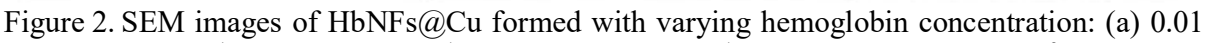
$\mathrm{mg} \mathrm{mL}-1$, (b) $0.02 \mathrm{mg} \mathrm{mL}^{-1}$, and (c) $0.05 \mathrm{mg} \mathrm{mL}^{-1}$ [PBS (10 mM, pH 6), $\mathrm{Cu}^{2+}(0.8 \mathrm{mM})$, $+4{ }^{\circ} \mathrm{C}, 3$ days incubation]. 
(a)

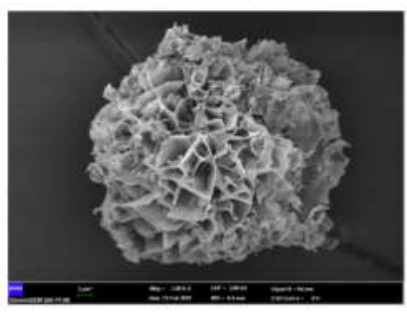

(b)

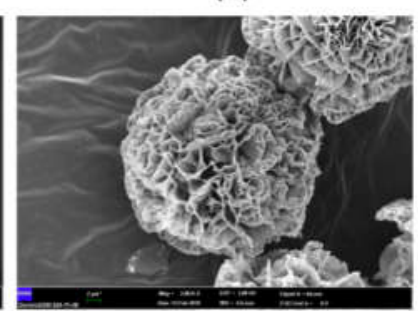

(c)

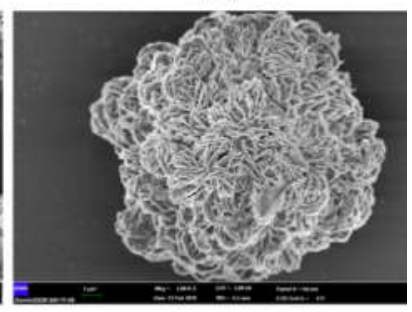

Figure 3. SEM images of HbNFs@Cu formed with varying hemoglobin concentration:(a) 0.01 $\mathrm{mg} \mathrm{mL}^{-1}$, (b) $0.02 \mathrm{mg} \mathrm{mL}^{-1}$, and (c) $0.05 \mathrm{mg} \mathrm{mL}^{-1}$ [PBS (10 mM, pH 8), $\mathrm{Cu}^{2+}(0.8 \mathrm{mM})$, $+4{ }^{\circ} \mathrm{C}, 3$ days incubation].

(a)

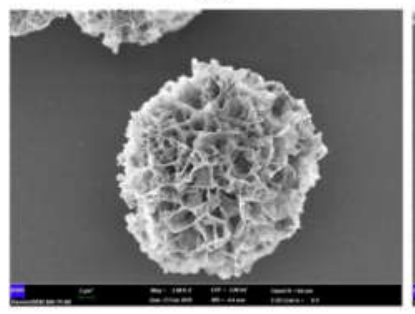

(b)

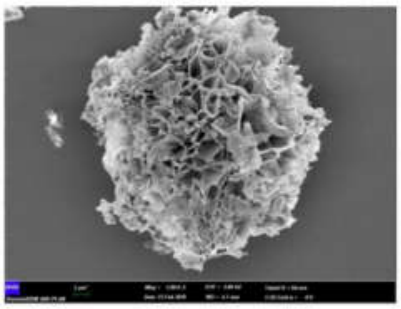

(c)

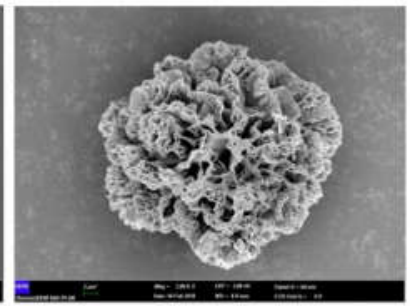

Figure 4. SEM images of HbNFs@Cu formed with varying hemoglobin concentration: (a) 0.01 $\mathrm{mg} \mathrm{mL}^{-1}$, (b) $0.02 \mathrm{mg} \mathrm{mL}^{-1}$, and (c) $0.05 \mathrm{mg} \mathrm{mL}^{-1}$ [PBS (10 mM, pH 9), $\mathrm{Cu}^{2+}(0.8 \mathrm{mM})$, $+4{ }^{\circ} \mathrm{C}, 3$ days incubation].

\section{Characterization of HbNFs@Cu}

The HbNFs@Cu synthesized under optimum conditions was characterized by EDX, XRD and FTIR analyses. The presence of $\mathrm{Cu}, \mathrm{P}, \mathrm{C}, \mathrm{N}$ and $\mathrm{O}$ in $\mathrm{HbNFs} @ \mathrm{Cu}$ was analyzed with EDX technique. Corresponding peaks of $\mathrm{Cu}, \mathrm{P}$, and $\mathrm{O}$ arose from the copper phosphate crystal structures. The presence of $\mathrm{Cl}$ was residual from the PBS buffer. The weight and atomic percentage of HbNFs@Cu are 30.35 and 9.45, respectively. The given XRD spectrum shows the peak positions and intensities of HbNFs@Cu. The diffraction peaks of HbNFs@Cu fit well with the crystal pattern from $\mathrm{Cu}_{3}\left(\mathrm{PO}_{4}\right)_{2} .3 \mathrm{H}_{2} \mathrm{O}$ (JCPDS card (00-022-0548) [30-32]. The peaks at $8,925^{\circ}, 12,819^{\circ}, 20,543 \circ, 29,555^{\circ}, 33,797 \circ, 37,281^{\circ}$, and 53,547॰ in the spectrum of HbNFs@Cu belong to $\mathrm{Cu}_{3}\left(\mathrm{PO}_{4}\right)_{2} \cdot 3 \mathrm{H}_{2} \mathrm{O}$ nanostructures, indicating the inorganic composition of the hybrid nanoflowers.

The chemical structures of HbNFs@Cu and free hemoglobin were compared by FTIR spectrums, where HbNFs@Cu accounts for all the peaks found in the free hemoglobin. These results show the coordination between carboxyl/amino groups and copper ion and prove that the hybrid structure was well crystallized. P-O group frequency observed around $\sim 550 \mathrm{~cm}^{-1}$ has shifted to frequencies of $\sim 558 \mathrm{~cm}^{-1}$ and $\sim 621 \mathrm{~cm}^{-1}$ in the immobilized structure. The specific bands titled Amid III $\left(\sim 1384 \mathrm{~cm}^{-1}\right)$, Amid II $\left(\sim 1523 \mathrm{~cm}^{-1}\right)$, and Amid III $\left(\sim 1643 \mathrm{~cm}^{-1}\right)$ were determined at $\sim 1400 \mathrm{~cm}^{-1}, 1532 \mathrm{~cm}^{-1}$, and $1633 \mathrm{~cm}^{-1}$ in the hybrid material, respectively. The peaks in the range of $\sim 2940-3300 \mathrm{~cm}^{-1}$ were attributed to the $-\mathrm{CH}_{2}$ and $-\mathrm{CH}_{3}$ groups. 
Peroxidase-like activity profiles of HbNFs@Cu on different substrate and pH conditions

The enzymatic activity of the HbNFs@Cu was systematically investigated. The peroxidase-like activities of the HbNFs@Cu were screened in the pH 5-9 range compared to free hemoglobin using different substrates such as guaiacol and ABTS. The amount of enzyme catalyzing the conversion of $1 \mathrm{mmol}$ ABTS/Guaiacol substrate in one minute was calculated.

Figure $5 \mathrm{a}$ and $5 \mathrm{~b}$ show the peroxidase-like activities demonstrated by the free hemoglobin protein to be very low in all screened $\mathrm{pH}$ parameters. When using guaiacol substrate, the highest peroxidase-like activity was obtained at pH 9 and was 0.52 EU/mg (Figure 5a). The HbNFs@Cu showed high activity against ABTS substrate in a wide $\mathrm{pH}$ range, but the highest activity was calculated as $2.350 \mathrm{EU} / \mathrm{mg}$ at $\mathrm{pH} 5$ (Figure 5b). According to the data, $\mathrm{pH} 5$ and ABTS substrate were determined optimal conditions for subsequent experiments. Unlike natural enzymes, nanoflowers with peroxidase-like activity offer an increased enzymatic activity at extreme conditions [33]. The HbNFs@Cu could act like a Fenton reagent in the presence of $\mathrm{H}_{2} \mathrm{O}_{2}$. In the presence of HRP/peroxidase-like enzyme or material and ABTS, $\mathrm{H}_{2} \mathrm{O}_{2}$ could oxidize ABTS to produce a pigmented $\mathrm{ABTS}^{++}$product [34]. The metal ions in the nanoflowers react with $\mathrm{H}_{2} \mathrm{O}_{2}$ to produce metal ${ }^{1+}$ in the potential mechanism for the Fenton reaction, then metal ${ }^{1+}$ and $\mathrm{H}_{2} \mathrm{O}_{2}$ interact to form a highly reactive hydroxyl radical $(\mathrm{OH})[28,34]$. Some studies have demonstrated that some copper compounds or iron compounds act as a Fenton-like reagent in an acidic environment, which can catalyze the substrate to produce a pigmented product in the presence of $\mathrm{H}_{2} \mathrm{O}_{2}$ [28] .

\section{Michaelis-Menten kinetic parameters of HbNFs@Cu}

To determine the optimal catalytic activities of HbNFs@Cu, the Lineaweaver-Burk plot was used for different concentrations of ABTS $\left(0.08-2.7 \mathrm{mM} \mathrm{mL}^{-1}\right)$. The kinetic parameters of free hemoglobin was not monitored because the peroxidase-like activity values were very low. $K_{M}$ and $V_{\max }$ values for HbNFs@Cu were $0.1357 \mathrm{mM} / \mathrm{mL}$ and $3.6995 \mathrm{EU} / \mathrm{mg}$, respectively (Figure 6). Both values were obtained at $\mathrm{pH} 5$, and other conditions previously described.

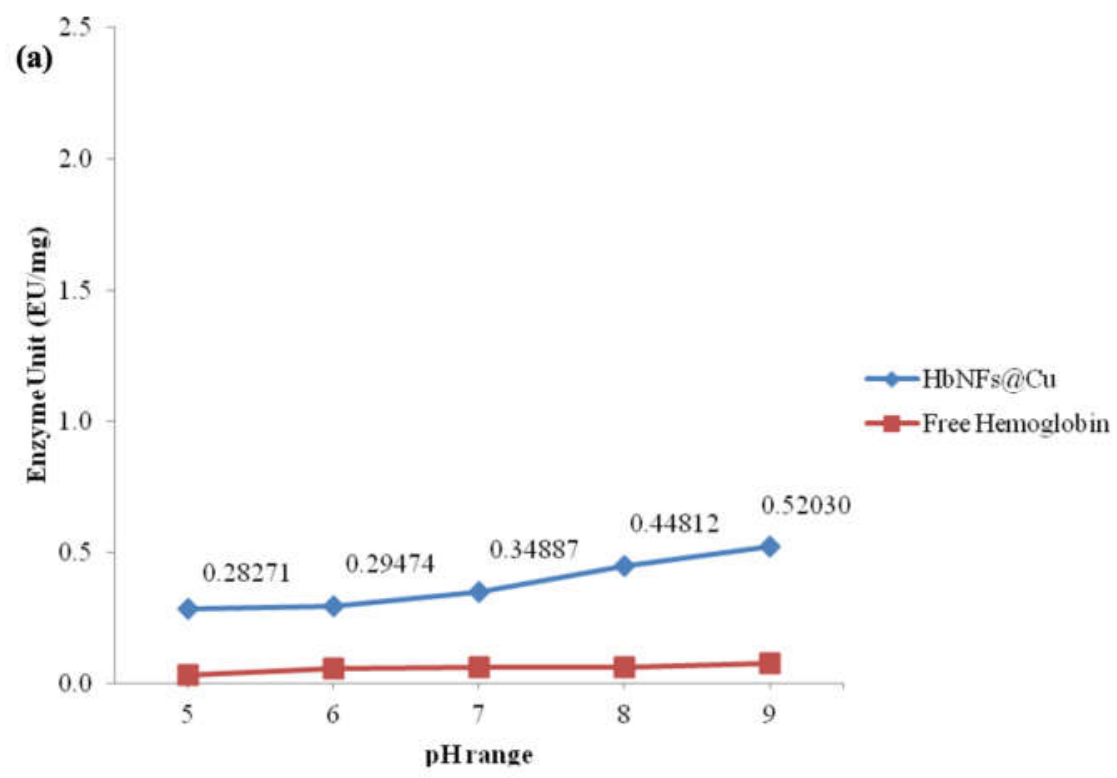

Bull. Chem. Soc. Ethiop. 2021, 35(3) 


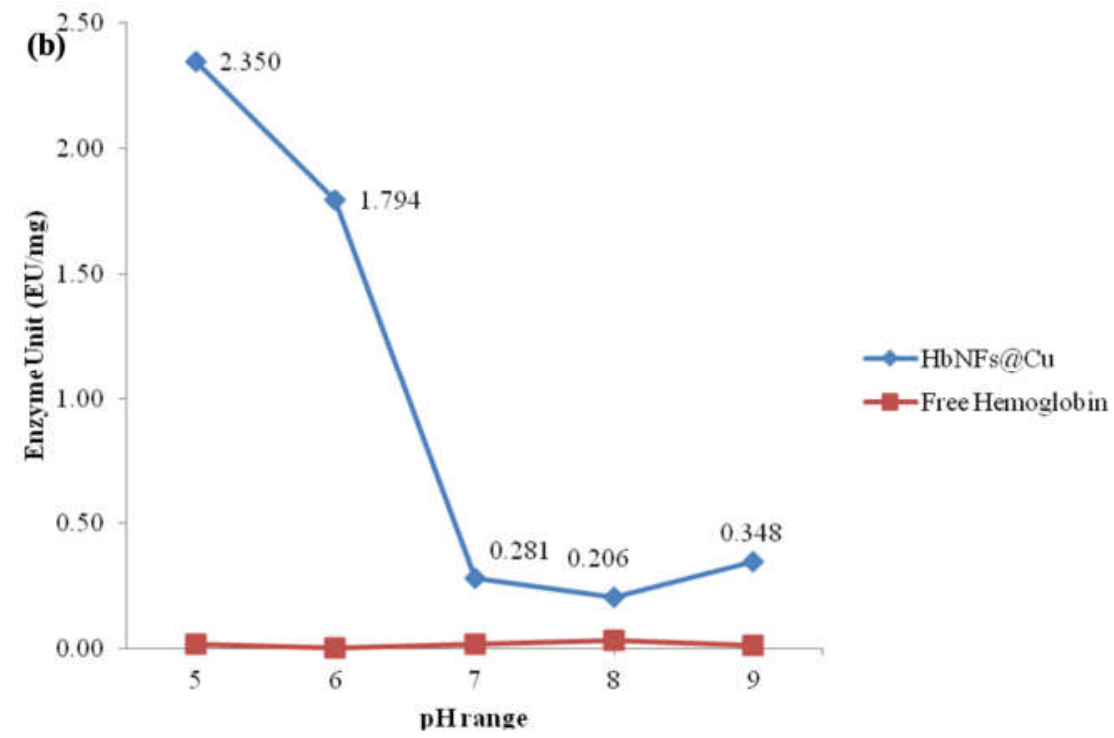

Figure 5. Comparison of peroxidase-like activities at different pH values of HbNFs@Cu and free hemoglobin using (a) guaiacol substrate and (b) ABTS substrate.

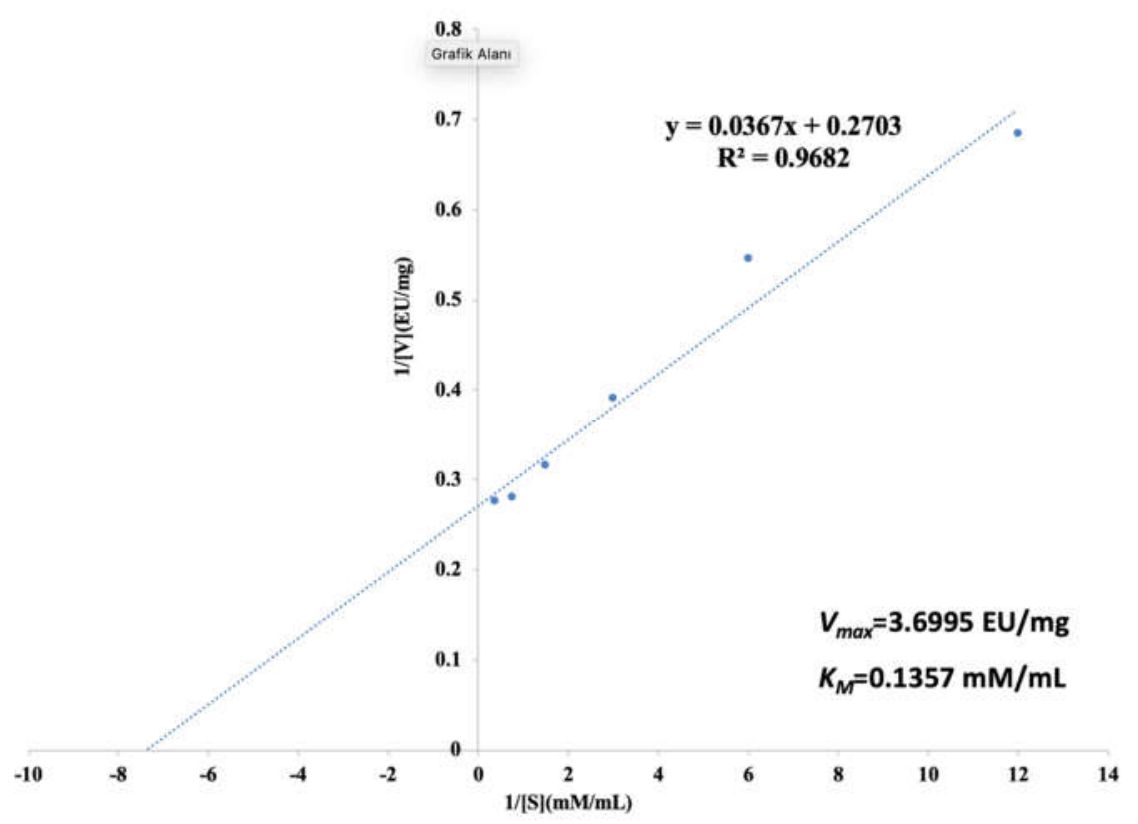

Figure 6. Lineweaver-Burk plot of the peroxidase-like activities of HbNFs@Cu at pH 5 using ABTS substrate.

Bull. Chem. Soc. Ethiop. 2021, 35(3) 


\section{Reusabilityof HbNFs@Cu}

As seen in Figure 7, HbNFs@Cu showed more than 57\% of initial enzymatic activity after ten uses. This result shows the durability of the material. Lee et al. [34] reported glutaraldehydetreated lipase nanoflowers exhibited more than $92 \%$ of their initial activity after 3 reuses. The decrease of enzymatic activity may be attributed to the scattering of the patels in the centrifugation process $[29,35]$.

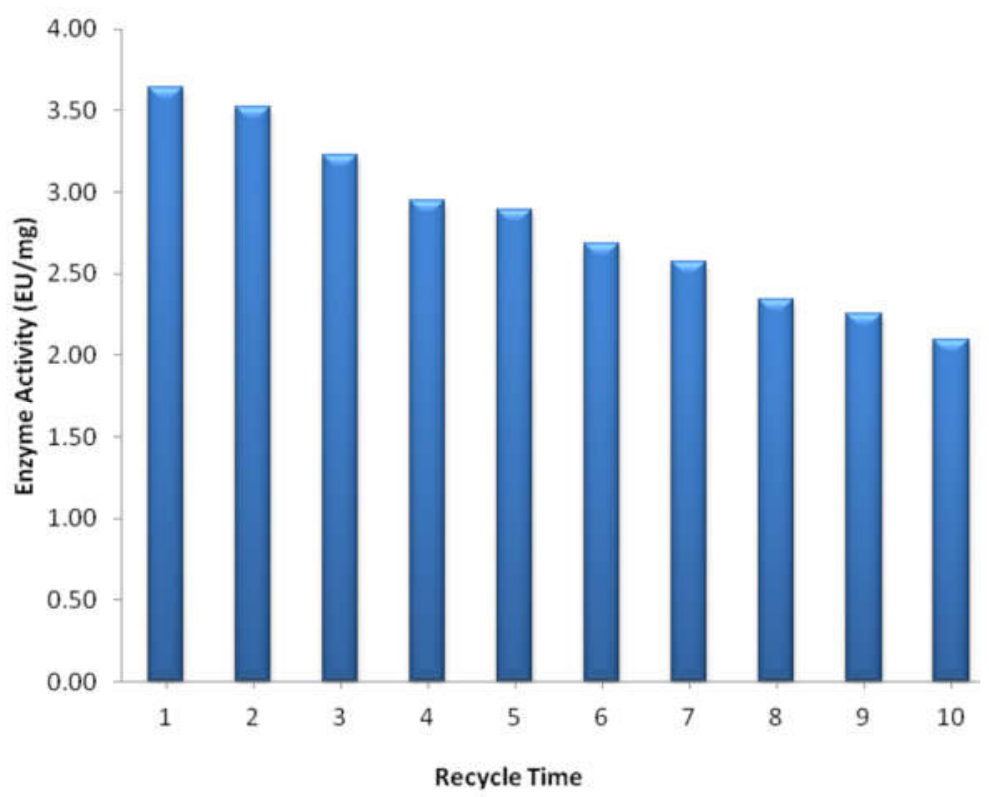

Figure. 7. Reusability of HbNFs@Cu.

Colorimetric and spectrophotometric detection of $\mathrm{H}_{2} \mathrm{O}_{2}$ using $\mathrm{HbNFs} @ \mathrm{Cu}$

The proposed biosensor system was based on colorimetric and spectrophotometric detection of catalyzed $\mathrm{H}_{2} \mathrm{O}_{2}$ using $\mathrm{HbNFs} @ \mathrm{Cu}$. After determining the optimum catalytic properties of the HbNFs@Cu, varying concentrations of $\mathrm{H}_{2} \mathrm{O}_{2}$ from $0.003 \mathrm{mM}$ to $0.667 \mathrm{mM}$ were tested. Figure 8 shows the colorimetric color changes. The color of wells gradually changed from colorless to dark green. As shown in Figure 9, a good linearity was determined in the range of 0.005-0.667 mM. It is clear that $\mathrm{H}_{2} \mathrm{O}_{2}$ can be determined as a colorimetric sensor in the range of $0.005-0.667 \mathrm{mM}$ in UV spectrum. In addition, the limit of detection was $0.005 \mathrm{mM}$, colorimetrically. To assess the specifity of biosensor system, the concentrations of $\mathrm{H}_{2} \mathrm{O}_{2}$ was decreased more. As shown in Figure 10 , a good linearity was determined in the range of $0.003-0.0042 \mathrm{mM}$, spectrometrically. The spectrometric limit of detection was determined to be $0.003 \mathrm{mM}$.

Lin et al. [14] investigated horseradish peroxidase (HRP)-inorganic hybrid nanoflowers as a colorimetric platform for visual detection of hydrogen peroxide and found sensitive visual detection of 20-500 $\mu \mathrm{M}$ linear range for hydrogen peroxide. Using Rhodamine $6 \mathrm{G}$ as a substrate for detection of $\mathrm{H}_{2} \mathrm{O}_{2}$, Gao et al. [24] investigated organic/inorganic hybrid nanoflowers containing hemoglobin as a biocatalyst to constructed colorimetric/fluorescent dual biosensors; their colorimetric/fluorescent dual biosensors exhibited two linear responses in the range of 2-10 $\mathrm{ppb}$ and 20-100 ppb for $\mathrm{H}_{2} \mathrm{O}_{2}$. They also synthesized flower-like hemoglobin- $\mathrm{Mn}_{3}\left(\mathrm{PO}_{4}\right)_{2}$ hybrid 
nanoflowers as an electrochemical sensing material to fabricate $\mathrm{H}_{2} \mathrm{O}_{2}$ electrochemical biosensor. Their biosensor displayed a linear response in the range of $20 \mathrm{nM}-3.6 \mu \mathrm{M}$ for $\mathrm{H}_{2} \mathrm{O}_{2}$ [25].

\begin{tabular}{|c|c|c|c|c|c|c|c|c|c|}
\hline$\left[\mathrm{H}_{2} \mathrm{O}_{2}\right] \mathrm{mM}$ & 0.667 & 0.333 & 0.167 & 0.083 & 0.042 & 0.021 & 0.010 & 0.005 & $\begin{array}{l}\text { Blind } \\
\text { Sampl }\end{array}$ \\
\hline $\begin{array}{c}\text { Colorimetric } \\
\text { Response }\end{array}$ & & & & & & & & & \\
\hline
\end{tabular}

Figure. 8. Colorimetric detection of $\mathrm{H}_{2} \mathrm{O}_{2}$ using HbNFs@ $@ \mathrm{Cu}$.

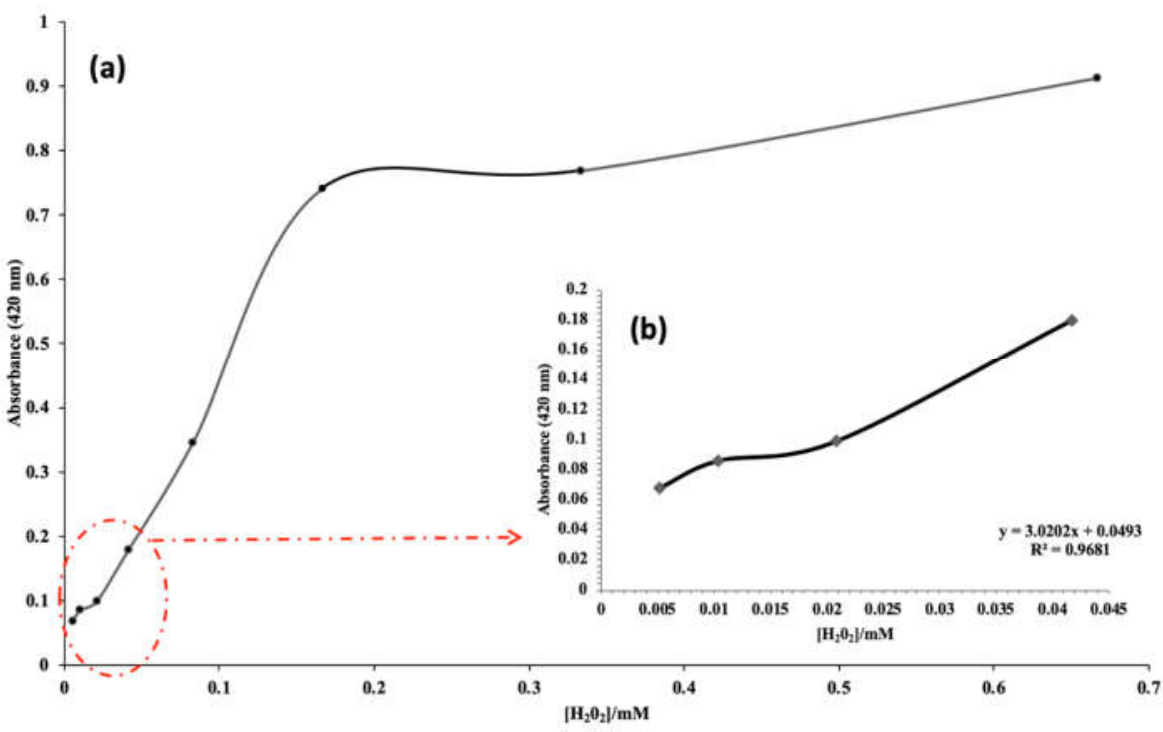

Figure 9. (a) Absorbance values at different concentrations of $\mathrm{H}_{2} \mathrm{O}_{2}$ and (b) linear working range of the colorimetric biosensor system at different concentrations of $\mathrm{H}_{2} \mathrm{O}_{2}(0.005-0.0042$ $\mathrm{mM})$.

In other previous studies, $\mathrm{Xu}$ et al. [22] fabricated a hemoglobin-silver sol in which the hemoglobin showed direct electrochemistry on a glass carbon electrode with range of $1 \times 10^{-6}$ to $2.5 \times 10^{-2} \mathrm{M}$ for detection of $\mathrm{H}_{2} \mathrm{O}_{2}$. Liu et al. [36] synthesized $\mathrm{TiO}_{2}$ modified reduced graphene oxide microspheres with immobilized hemoglobin to fabricate a mediator-free biosensor for detection $\mathrm{H}_{2} \mathrm{O}_{2}$ within the linear range of 0.1-360 $\mu \mathrm{M}$. Wang et al. [37] reported that tyrosinefunctionalized tetraphenylethene leads to fluorescence emission turn-on and fast detection of $\mathrm{H}_{2} \mathrm{O}_{2}$ with high sensitivity and selectivity. The fluorogenic biosensor indicated a highly selective enzymatic reactions with $0-50 \mu \mathrm{M}$ linear range. Teodoro et al. [38] produced silver nanoparticles that included polysaccharide (cellulose nanowhiskers), and tested as a colorimetric probe for $\mathrm{H}_{2} \mathrm{O}_{2}$ detection. They determined the sensitivity of the colorimetric assay to lie within the range of $0.01 \mu \mathrm{M}$ to $600 \mu \mathrm{M} \mathrm{H} \mathrm{H}_{2} \mathrm{O}_{2}$. Qi et al. [39] designed a mediator-free $\mathrm{H}_{2} \mathrm{O}_{2}$ biosensor by immobilizing $\mathrm{Hb}$ on multiwalled carbon nanotubes modified with glassy carbon electrode with a linear in the concentration range from $6.0 \mu \mathrm{M}$ to $6.0 \mathrm{mM}$. Wan and co-workers [40] explained the 
potential of nanozymes based on carbonaceous nanomaterials with their high stability and good biocompatibility for a colorimetric and fluorescent dual modality platform capable of detecting $\mathrm{H}_{2} \mathrm{O}_{2}$ and biomolecules (ascorbic acid-AA, acid phosphatase-ACP). Jamil and co-workers [41] obtained a $\mathrm{Cr}_{2} \mathrm{O}_{3}-\mathrm{TiO}_{2}$-modified biomimetic paperbased-nanosensor to detect colorimetric sensing of hydrogen peroxide. This paper-based colorimetric platform gave improved analytics with a linear range of $0.005-100 \mu \mathrm{M}$ and a $0.003 \mu \mathrm{M}$ limit of detection. Jiang and co-workers [42] synthesized the D-amino acid incorporating nanoflowers with peroxidase-like activity and a diameter of 10-15 $\mu \mathrm{m}$. The nanoflowers were used as a component for determining the level of glutathione in the presence of TMB and $\mathrm{H}_{2} \mathrm{O}_{2}$.

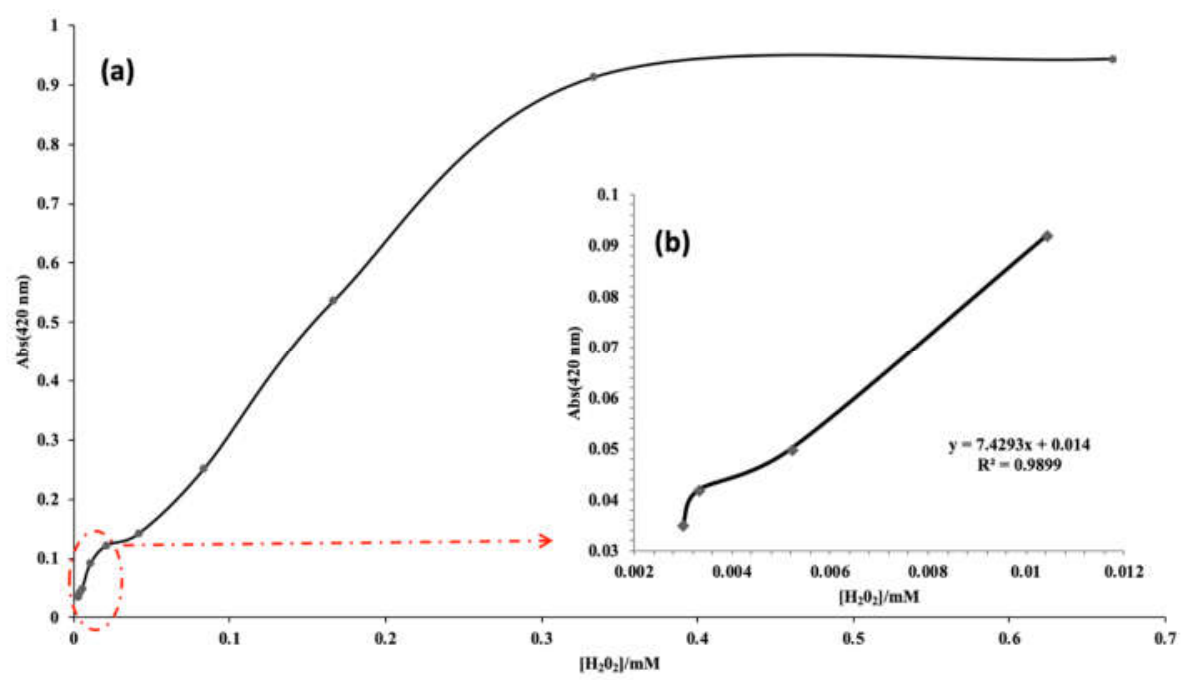

Figure 10. (a) UV absorption spectrum values in the presence of different concentrations of $\mathrm{H}_{2} \mathrm{O}_{2}$ (0.003-0.667 $\mathrm{mM}$ and (b) linear working range of the spectrometric biosensor system at varying concentrations of $\mathrm{H}_{2} \mathrm{O}_{2}(0.003-0.0042 \mathrm{mM})$.

\section{CONCLUSION}

There has been using a various hybrid materials obtained with organic-inorganic hybrid nanoflowers preparation method for analytical assays in recently. In this article, HbNFs@Cu was prepared at varying pH values and protein concentrations. The HbNFs@Cu product had a very homogeneous structure and an average size of 9-10 $\mu \mathrm{m}$ under the optimized experimental conditions. The encapsulation and weight efficiency was $100 \%$ and $6.7 \%$, respectively. Peroxidase-like activities were investigated against various substrates (ABTS and guaiacol) for HbNFs@Cu.HbNFs@Cu performed to the enhanced peroxidase-like catalytic activity and reusability. These peroxidase-like activities provided both colorimetric and spectrometric assays for detection of $\mathrm{H}_{2} \mathrm{O}_{2}$. The linear operating range, detected colorimetrically as $\mathrm{H}_{2} \mathrm{O}_{2}$ sensor, was 0.005-0.0042 mM, while the linear operating range, detected spectrometrically, was 0.003-0.0042 $\mathrm{mM}$. These results showed that hemoglobin-based organic-inorganic hybrid materials can be used in potential applications to sense for $\mathrm{H}_{2} \mathrm{O}_{2}$. 


\section{ACKNOWLEDGEMENTS}

This study was supported by Scientific Research Projects Committee of Nevsehir Haci Bektas Veli University (Project No: BAP18F10). We appreciate Yasin Polat at the Nevsehir Haci Bektas Veli University for assistance with XRD analysis. We also appreciate the technical assistance from Ihsan Aksit for SEM, EDX and FTIR analysis at Erciyes University. Please contact to the corresponding author for supporting data.

\section{REFERENCES}

1. Gulmez, C.; Altinkaynak, C.; Özdemir, N.; Atakisi, O. Proteinase K hybrid nanoflowers (PHNFs) as a novel nanobiocatalytic detergent additive. Int. J. Biol. Macromol. 2018, 119, 803810.

2. Altinkaynak, C.; Kocazorbaz, E.; Özdemir, N.; Zihnioglu, F. Egg white hybrid nanoflower (EW-HNF) with biomimetic polyphenol oxidase reactivity: Synthesis, characterization and potential use in decolorization of synthetic dyes. Int. J. Biol. Macromol. 2018, 109, 205-211.

3. Al-Maqdi, K.A.; Bilal, M.; Alzamly, A.; Iqbal, H.M.N.; Shah, I.; Ashraf, S.S. Enzyme-loaded flower-shaped nanomaterials: A versatile platform with biosensing, biocatalytic, and environmental promise. Nanomaterials 2021, 11, 1460.

4. Eskin, A.; Ekremoglu, M.; Altinkaynak, C.; Özdemir, N. Effects of organic-inorganic hybrid nanoflowers' framework on hemocytes and enzymatic responses of the model organism, Galleria mellonella (Lepidoptera: Pyralidae). Int. J. Trop. Insect. Sci. 2021, doi: 10.1007/s42690-021-00551-2.

5. Liu, Y.; Shao, X.; Kong, D.; Li, G.; Li, Q. Immobilization of thermophilic lipase in inorganic hybrid nanoflower through biomimetic mineralization. Colloids Surf. B: Biointerfaces 2021, 197, 111450.

6. Özdemir, N.; Altinkaynak, C.; Türk, M.; Geçili, F.; Tavlaşoğlu, S. Amino acid-metal phosphate hybrid nanoflowers (AaHNFs): Their preparation, characterization and antioxidant capacities. Polym. Bull. 2021, DOI: https://doi.org/10.1007/s00289-021-03973-7.

7. Aydemir, D.; Gecili, F.; Özdemir, N.; Nuray Ulusu, N. Synthesis and characterization of a triple enzyme-inorganic hybrid nanoflower (TrpE@ihNF) as a combination of three pancreatic digestive enzymes amylase, protease and lipase. J. Biosci. Bioeng. 2020, 129, 679686.

8. Qiu, X.; Xiang, X.; Liu, T.; Huang, H.; Hu, Y. Fabrication of an organic-inorganic nanocomposite carrier for enzyme immobilization based on metal-organic coordination. Process Biochem. 2020, https://doi.org/10.1016/j.procbio.2020.05.007.

9. Shende, P.; Kasture, P.; Gaud, R.S. Nanoflowers: The future trend of nanotechnology for multi-applications. Artif. Cells, Nanomed. Biotechnol. 2018, 46, 413-422.

10. Ahammad, A.J.S. Hydrogen peroxide biosensors based on horseradish peroxidase and hemoglobin. J. Biosens. Bioelectron. 2012, s9, https://doi.org/10.4172/2155-6210.S9-001.

11. Lee, T.; Kim, T.-H.; Yoon, J.; Chung, Y.-H.; Lee, J.; Choi, J.-W. Investigation of hemoglobin/gold nanoparticle heterolayer on micro-gap for electrochemical biosensor application. Sensors 2016, 16, 660.

12. Mathew, M.; Sandhyarani, N.A Novel electrochemical sensor surface for the detection of hydrogen peroxide using cyclic bisureas/gold nanoparticle composite. Biosens. Bioelectron. 2011, 28, 210-215.

13. Jv, Y.; Li, B.; Cao, R. Positively-charged gold nanoparticles as peroxidase mimic and their application in hydrogen peroxide and glucose detection. Chem. Commun. (Camb.) 2010, 46, 8017-8019.

14. Lin, Z.; Xiao, Y.; Yin, Y.; Hu, W.; Liu, W.; Yang, H. Facile synthesis of enzyme-inorganic hybrid nanoflowers and its application as a colorimetric platform for visual detection of hydrogen peroxide and phenol. ACS Appl. Mater. Interfaces 2014, 6, 10775-10782.

Bull. Chem. Soc. Ethiop. 2021, 35(3) 
15. Mu, J.; Zhang, L.; Zhao, M.; Wang, Y. Catalase mimic property of $\mathrm{Co}_{3} \mathrm{O}_{4}$ nanomaterials with different morphology and its application as a calcium sensor. ACS Appl. Mater. Interfaces 2014, 6, 7090-7098.

16. Narwal, V.; Yadav, N.; Thakur, M.; Pundir, C.S. An amperometric $\mathrm{H}_{2} \mathrm{O}_{2}$ biosensor based on hemoglobin nanoparticles immobilized on to a gold electrode. Biosci. Rep. 2017, 37, https://doi.org/10.1042/BSR20170194.

17. Sezgintürk, M.K.; Dinçkaya, E. $\mathrm{H}_{2} \mathrm{O}_{2}$ Determination by a biosensor based on hemoglobin. Prep. Biochem. Biotechnol. 2009, 39, 1-10. https://doi.org/10.1080/10826060802589361.

18. Jo, J.; Yoon, J.; Lee, T.; Cho, H.-Y.; Lee, J.-Y.; Choi, J.-W. $\mathrm{H}_{2} \mathrm{O}_{2}$ biosensor consisted of hemoglobin-DNA conjugate on nanoporous gold thin film electrode with electrochemical signal enhancement. Nano Convergence 2019, 6, 1. https://doi.org/10.1186/s40580-0180172-z.

19. Zhang, K.; Cai, R.; Chen, D.; Mao, L. Determination of hemoglobin based on its enzymatic activity for the oxidation of O-phenylenediamine with hydrogen peroxide. Anal. Chim. Acta 2000, 413, 109-113.

20. Zhang, K.; Mao, L.; Cai, R. Stopped-flow spectrophotometric determination of hydrogen peroxide with hemoglobin as catalyst. Talanta 2000, 51, 179-186.

21. Guo, F.; Xu, X.X.; Sun, Z.Z.; Zhang, J.X.; Meng, Z.X.; Zheng, W.; Zhou, H.M.; Wang, B.L.; Zheng, Y.F. A novel amperometric hydrogen peroxide biosensor based on electrospun $\mathrm{Hb}-$ collagen composite. Colloids Surf. B: Biointerfaces 2011, 86, 140-145.

22. Xu, Y.; Hu, C.; Hu, S. A hydrogen peroxide biosensor based on direct electrochemistry of hemoglobin in $\mathrm{Hb}-\mathrm{Ag}$ sol films. Sens. Actuators B: Chem. 2008, 130, 816-822.

23. Gao, F.; Yuan, R.; Chai, Y.; Tang, M.; Cao, S.; Chen, S. Amperometric third-generation hydrogen peroxide biosensor based on immobilization of $\mathrm{Hb}$ on gold nanoparticles/cysteine/poly( $p$-aminobenzene sulfonic acid)-modified platinum disk electrode. Colloids Surf. A: Physicochem. Eng. Aspects 2007, 295, 223-227.

24. Gao, J.; Liu, H.; Pang, L.; Guo, K.; Li, J. A biocatalyst and colorimetric/fluorescent dual biosensors of $\mathrm{H}_{2} \mathrm{O}_{2}$ constructed via hemoglobin- $\mathrm{Cu}_{3}\left(\mathrm{PO}_{4}\right)_{2}$ organic/inorganic hybrid nanoflowers. ACS Appl. Mater. Interfaces 2018, 10, https://doi.org/10.1021/acsami.8b10968.

25. Gao, J.; Liu, H.; Tong, C.; Pang, L.; Feng, Y.; Zuo, M.; Wei, Z.; Li, J. Hemoglobin-Mn $\mathrm{M}_{3}\left(\mathrm{PO}_{4}\right)_{2}$ hybrid nanoflower with opulent electroactive centers for high-performance hydrogen peroxide electrochemical biosensor. Sens. Actuators B: Chem. 2020, 307, 127628.

26. Wu, D.; Feng, M.; Wang, Z.-X.; Qiao, K.; Tachibana, H.; Cheng, X.-J. Molecular and biochemical characterization of key enzymes in the cysteine and serine metabolic pathways of Acanthamoeba castellanii. Parasite Vectors 2018, 11, 604.

27. Wang, K.; Wang, J.; Hu, W.; Zhang, Y.; Zhi, F.; Zhou, Z.; Wu, J.; Hu, Y. Acid denaturation inducing self-assembly of curcumin-loaded hemoglobin nanoparticles. Materials 2015, 8 , 8701-8713.

28. Huang, Y.; Ran, X.; Lin, Y.; Ren, J.; Qu, X. Self-assembly of an organic-inorganic hybrid nanoflower as an efficient biomimetic catalyst for self-activated tandem reactions. Chem. Commun. 2015, 51, 4386-4389.

29. Nadar, S.S.; Gawas, S.D.; Rathod, V.K. Self-assembled organic-inorganic hybrid glucoamylase nanoflowers with enhanced activity and stability. Int. J. Biol. Macromol. 2016, 92, 660-669.

30. Batule, B.S.; Park, K.S.; Kim, M.I.; Park, H.G. Ultrafast sonochemical synthesis of proteininorganic nanoflowers. Int. J. Nanomedicine 2015, 10, 137-142.

31. Ge, J.; Lei, J.; Zare, R.N. Protein-inorganic hybrid nanoflowers. Nat. Nanotechnol. 2012, 7 , $428-432$.

32. Somturk, B.; Hancer, M.; Ocsoy, I.; Özdemir, N. Synthesis of copper ion incorporated horseradish peroxidase-based hybrid nanoflowers for enhanced catalytic activity and stability. Dalton Trans. 2015, 44, 13845-13852. 
33. Singh, S. Nanomaterials exhibiting enzyme-like properties (nanozymes): Current advances and future perspectives. Front. Chem. 2019, 7, 46.

34. Wei, $\mathrm{H}$; W Wang, E. $\mathrm{Fe}_{3} \mathrm{O}_{4}$ magnetic nanoparticles as peroxidase mimetics and their applications in $\mathrm{H}_{2} \mathrm{O}_{2}$ and glucose detection. Anal. Chem. 2008, 80, 2250-2254.

35. Lee, H.R.; Chung, M.; Kim, M.I.; Ha, S.H. Preparation of glutaraldehyde-treated lipaseinorganic hybrid nanoflowers and their catalytic performance as immobilized enzymes. Enzyme Microb. Technol. 2017, 105, 24-29.

36. Wang, X.; Shi, J.; Li, Z.; Zhang, S.; Wu, H.; Jiang, Z.; Yang, C.; Tian, C. Facile one-pot preparation of chitosan/calcium pyrophosphate hybrid microflowers. ACS Appl. Mater. Interfaces 2014, 6, 14522-14532.

37. Liu, H.; Guo, K.; Duan, C.; Dong, X.; Gao, J. Hollow $\mathrm{TiO}_{2}$ modified reduced graphene oxide microspheres encapsulating hemoglobin for a mediator-free biosensor. Biosens. Bioelectron. 2017, 87, 473-479.

38. Wang, X.; Hu, J.; Zhang, G.; Liu, S. Highly selective fluorogenic multianalyte biosensors constructed via enzyme-catalyzed coupling and aggregation-induced emission. J. Am. Chem. Soc. 2014, 136, 9890-9893.

39. Teodoro, K.B.R.; Migliorini, F.L.; Christinelli, W.A.; Correa, D.S. Detection of hydrogen peroxide $\left(\mathrm{H}_{2} \mathrm{O}_{2}\right)$ using a colorimetric sensor based on cellulose nanowhiskers and silver nanoparticles. Carbohydr. Polym. 2019, 212, 235-241.

40. Chen, S.; Yuan, R.; Chai, Y.; Zhang, L.; Wang, N.; Li, X. Amperometric third-generation hydrogen peroxide biosensor based on the immobilization of hemoglobin on multiwall carbon nanotubes and gold colloidal nanoparticles. Biosens. Bioelectron. 2007, 22, 1268-1274.

41. Wan, Y.; Zhao, J.; Deng, X.; Chen, J.; Xi, F.; Wang, X. Colorimetric and fluorescent dualmodality sensing platform based on fluorescent nanozyme. Front. Chem. 2021, 9, 774486.

42. Jamil, S.; Nasir, M.; Ali, Y.; Nadeem, S.; Rashid, S.; Javed, M.Y.; Hayat, A. $\mathrm{Cr}_{2} \mathrm{O}_{3}-\mathrm{TiO}_{2}-$ modified filter paper-based portable nanosensors for optical and colorimetric detection of hydrogen peroxide. ACS Omega 2021, 6, 23368-23377.

43. Jiang, N.; Zhang, C.; Li, M.; Li, S.; Hao, Z.; Li, Z.; Wu, Z.; Li, C. The fabrication of amino acid incorporated nanoflowers with intrinsic peroxidase-like activity and its application for efficiently determining glutathione with TMB radical cation as indicator. Micromachines (Basel) 2021, 12, 1099. 